\title{
Stakeholder management theory meets CSR practice in Swedish mining
}

\author{
Helena Ranängen ${ }^{1}$
}

Received: 26 April 2016 / Accepted: 21 November 2016/Published online: 12 December 2016

(C) The Author(s) 2016. This article is published with open access at Springerlink.com

\begin{abstract}
CSR needs to be implemented into every level of an organization to have a meaningful impact, and management systems are proven useful for CSR practice. Benefits of integrating all CSR aspects into a sustainability management system are often claimed. Stakeholder theory can advance CSR practice. This case study explores how a company reacts to and appropriates stakeholder theory through interviews and workshops with the top management of corporate responsibility. This is an empirical addition to the dominant conceptual contributions to stakeholder management framed within the concept of management system thinking. The focus is on identification of stakeholders and the estimation of "who and what really counts". This study support conceptual papers and suggest Mitchell and colleagues' model for the initial step of SMS. It shows that theory easily can be practised and that it works well. The company highlighted the discussions where it had to look at stakeholders from different perspectives.
\end{abstract}

Keywords Stakeholder theory · Stakeholder management . Management systems $\cdot$ Corporate responsibility $\cdot$ Corporate social responsibility $\cdot \mathrm{CSR}$

\section{Introduction}

Corporate social responsibility (CSR) can be seen as the corporate contribution to sustainable development (ISO 2010). CSR should not only be philanthropy and compensation for

Helena Ranängen

helena.ranangen@1tu.se

1 Industrial Environmental Management, Luleå University of Technology, 97187 Luleå, Sweden irresponsible practice but also integrated into daily business (Hörisch et al. 2014). Scholars suggest that CSR needs to be implemented into every level of an organization to have a meaningful impact (Castka et al. 2004; Zadek 2004; Asif et al. 2011b; Shahin and Zairi 2007). A recent review of CSR practice in the extractive industry has shown that it is the code of conduct, the sustainability reports and community involvement that foremost represent sustainability management (Ranängen and Zobel 2014). Therefore, there is a need for further research on the actual implementation of CSR and the integration of those activities into core business processes (Asif et al. 2011b).

Established management systems are useful for CSR practice, and frameworks derive from various standards (Ciliberti et al. 2008; Esquer-Peralta et al. 2008; Holton et al. 2010; Rocha et al. 2007; Sebhatu and Enquist 2007; Sullivan 2004; Castka et al. 2004). Management systems refer to the management of an organization in a comprehensive, systematic, planned and documented manner. It includes the organizational structure, planning and resources for developing, implementing and maintaining policy for CSR aspects like the environment, occupational health and safety, energy, etc. The PDCA methodology which stands for "Plan, Do, Check, Act" (Deming 1986) is often applied to achieve continual improvements. The benefits of integrating all aspects of CSR into one sustainability management system (SMS) are often claimed (Rocha et al. 2007; Asif et al. 2011b). The SMS is then a tool helping companies in their sustainability performance (Esquer-Peralta et al. 2008). However, critical researchers believe that SMS would benefit from a more externally focused stakeholder-driven and value-based approach (Kemp et al. 2006) and instead of "doing things right" should focus on "doing the right things" since companies are confronted with a range of stakeholders, each of them having specific values and interests (Zwetsloot 2003). 
Stakeholder theory can be considered a CSR theory (Melé 2008) that can be usefully applied in CSR practice (Hörisch et al. 2014) and scholars should continue to explore how traditional theories, like stakeholder theory, can be used to advance CSR practice (Starik et al. 2000). Efforts in integrating stakeholder management into SMS have been made; Singh et al. (2007) talk about stakeholder mapping and stakeholder consultation, Asif et al. (2011a) advocate an identification of key stakeholders, Rocha et al. (2007) see the stakeholders as the "battery" that powers the rest of the SMS, and Asif et al. (2011b) recommend "top-down" and "bottom-up" approaches to CSR that identifies stakeholders and stakeholder needs. Nevertheless, these frameworks are almost always conceptual and very seldom describe how stakeholder management should be performed. More empirical research is needed to establish how these frameworks unfold in practice (Asif et al. 2011b) and more specifically the stakeholder assessment process and its translation into CSR objectives and policies (Castka et al. 2004).

Hence, this paper describes how a company reacts to and appropriates established stakeholder theory i.e. to test its applicability. This is an important empirical addition to the otherwise often conceptual contributions to stakeholder management framed within the concept of management system thinking. The focus is on the planning phase in the PDCA methodology i.e. the identification of stakeholders and the estimation of "who and what really counts".

Following this introduction, the theoretical framework is presented. Then comes the methodology followed by the organizational context. In the results section, the empirical findings are presented. Finally, in the last section, these findings are discussed and conclusions are drawn.

\section{Three seminal stakeholder publications}

The theoretical framework is based on three publications on stakeholder theory with high academic legitimacy; Freeman (1984), Freeman et al. (2007), and Mitchell et al. (1997). The book "Strategic Management: A Stakeholder approach" (Freeman 1984) is described by many as "a classic book" (Laplume et al. 2008; Weber and Wasieleski 2003; Minoja 2012) and the formal, academic beginning of stakeholder theory (Donaldson and Preston 1995). The book is cited 16,063 times in Google Scholar as of October 2014 and continues to be cited, as stakeholder theory continues to attract management researchers (Laplume et al. 2008). The book "Managing for stakeholders: Survival, reputation, and success" (Freeman et al. 2007) is an updated retelling of Freeman's classic story (Stieb 2009) and is cited 437 times in Google Scholar as of October 2014. Both books are written for practitioners and are therefore very usable for the purpose of this study.
Mitchell et al.'s (1997) framework has become popular (Parent and Deephouse 2007), as evidenced by 6345 citations according to Google Scholar in published work as of October 2014. It is one of the most significant contributions to stakeholder management (Missonier and Loufrani-Fedida 2014) and the most comprehensive work in answering who the stakeholders are and to whom the company should pay attention (Frooman 1999). Dunfee (2008) states that this is the most detailed attempt to provide a relevant sorting among stakeholders and that their discussion and analysis provide helpful guidance. Despite that, there has been limited research using the Mitchell et al. (1997) framework as a tool for empirical analysis articles that used power, legitimacy and urgency (Parent and Deephouse 2007). These three important publications are outlined below.

\section{The stakeholder view of the firm}

Freeman (1984) saw a need for a framework that included not only the customers, owners, employees and suppliers but also governments, competitors, consumer advocates, environmentalists, special interest groups (SIG) and media. This resulted in the well-known "stakeholder view of the firm", where the company is placed in the centre, separate from the stakeholders and the collaboration is symbolized with arrows, see Fig. 1. The definition of a stakeholder is any group or individual who can "affect or is affected by the achievement of the firm's objectives".

He argues that all organizations have stakeholders and organizations must take stakeholder groups into account in order to be successful in the current and future environment. "Stakeholder management", as a concept, refers to the necessity for an organization to manage the relationships with its stakeholder groups in an action-oriented way. First, we must understand who the stakeholders are, visualized by a stakeholder map (for examples see Figs. 1 and 2) and what the stakes are. Second, we must understand the organizational processes used to manage the organization's relationships with the stakeholders. In this paper, the focus is on the strategic management process where stakeholders are identified and stakeholder-manager relationships are evaluated. Finally, we must understand the set of transactions or bargains among the organization and its stakeholders and ascertain whether these negotiations "fit" with the stakeholder map and the organizational processes for stakeholders.

\section{The two-tier stakeholder map}

In 2007, Freeman et al. (2007) argue that the conditions for business have changed since when Freeman (1984) wrote his classic book. We have experienced a globalization of capital markets and an emergence of powerful information technologies. Along with the liberalization of markets has come a 


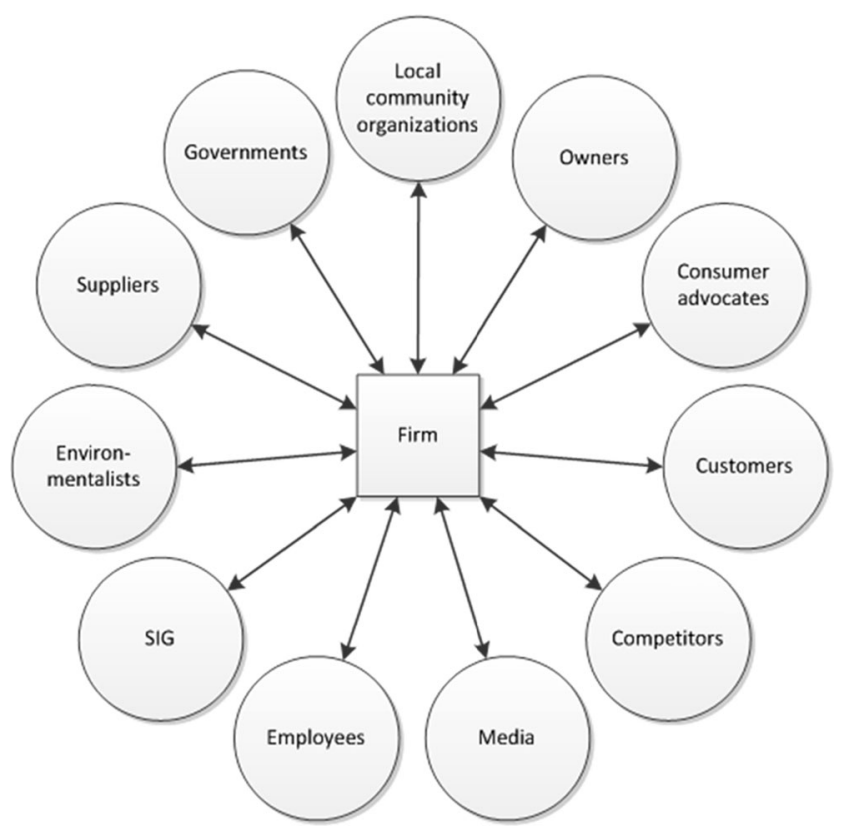

Fig. 1 The "stakeholder view of the firm" adopted from Freeman (1984)

liberalization of political institutions around the world. We have discovered that we need to take better care of the environment. Environmental awareness, championed by NGOs, has been spread globally. These trends have changed the primary business relationships with customers, suppliers, employees, financiers, community, competitors, etc. (Freeman et al. 2007; Jensen and Sandström 2011). As a response, Freeman et al. (2007) have developed the "Stakeholder view of the firm" into a two-tier stakeholder map (see Fig. 2).

Business can be understood as a set of relationships among groups that have a stake in the activities that make up the business. Business is about how stakeholders and managers

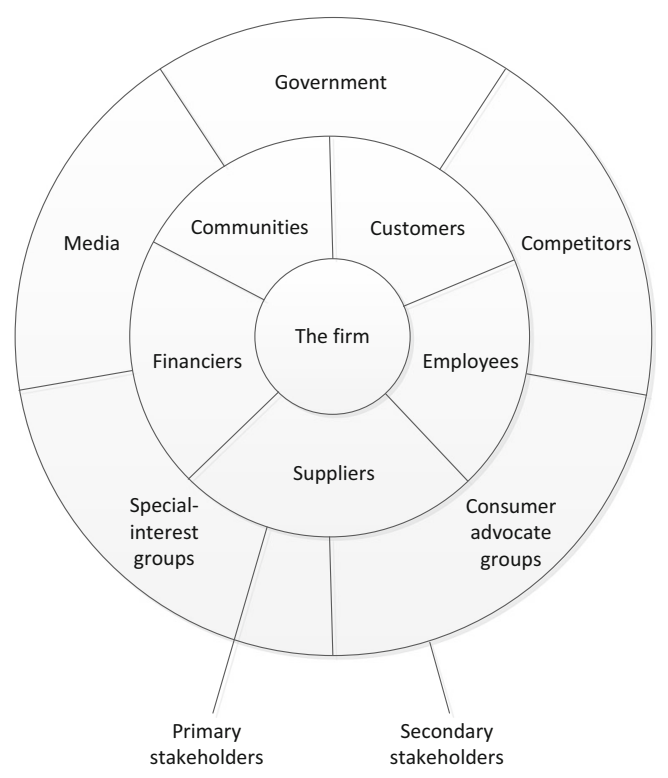

Fig. 2 The basic two-tier stakeholder map from Freeman et al. (2007) interact and create value. The manager's job is to manage and shape these relationships, hence the term "managing for stakeholders" (Freeman et al. 2007). There are two important kinds of stakeholders. First, the "primary" stakeholders, which indicate that they are vital to the continued growth and survival of any business. These stakeholders are customers, employees, suppliers, financiers and communities, and if the support from any of these stakeholders is taken away, the result will be an unsustainable business. Business and managers must pay a special kind of attention to these groups. Second, we need to look at the broader business environment on a routine basis and in particular be concerned with those groups that can affect our primary relationships. These groups are the "secondary" stakeholders; activists, governments, competitors, media, environmentalists, corporate critics and special interest groups. Figure 2 shows where these two kinds of stakeholders fit into the overall scheme.

\section{Evaluating stakeholder-manager relationships}

Mitchell et al. (1997) present a more sophisticated model for stakeholder management with a theory that is based on stakeholders possessing one or more of the three relationship attributes: power, legitimacy and urgency. The theory is supposed to help management to separate stakeholders from non-stakeholders, and to explain to whom and to what managers actually should pay attention. The descriptions and definitions of the attributes are presented in Table 1.

Entities with no power, legitimacy or urgency in relation to the firm are not stakeholders. "Latent stakeholders" are identified by their possession of only one of the attributes. With limited time, energy and other resources, managers may well do nothing about this category. "Expectant stakeholders" are identified by their possession of two of the attributes, and the level of engagement between managers and these expectant stakeholders is likely to be higher. The combination of all three attributes defines "definitive stakeholders", to whom managers give priority. The model is presented more in detail in Fig. 3 and Table 2.

\section{Methodology}

In order to explore if the seminal stakeholder publications can be useful, a case study was chosen as a research method. Casestudy research is relevant if the questions require an extensive and in-depth description of a phenomenon (Yin 2009) and it allows the researcher to investigate social phenomena in reallife contexts (Miles and Huberman 1994; Yin 2009). Furthermore, single case studies are particularly powerful in exploring a phenomenon in its context (Eisenhardt and Graebner 2007). The mining and metals company Boliden $\mathrm{AB}$ was selected as the case company based on high CSR 
Table 1 The relationship attributes with explanations and definitions based on the work of Mitchell et al. (1997) presented for the focus group

\begin{tabular}{|c|c|c|}
\hline $\begin{array}{l}\text { Relationship } \\
\text { attribute }\end{array}$ & Description & Definition \\
\hline Power & $\begin{array}{l}\text { The stakeholder's power } \\
\text { to influence the firm }\end{array}$ & $\begin{array}{l}\text { A relationship among social actors in which one } \\
\text { social actor, A, can get another social actor, B, } \\
\text { to do something that B would not have } \\
\text { otherwise done }\end{array}$ \\
\hline Legitimacy & $\begin{array}{l}\text { The legitimacy of the stakeholder's } \\
\text { relationship with the firm }\end{array}$ & $\begin{array}{l}\text { A generalized perception or assumption that the } \\
\text { actions of an entity are desirable, proper or } \\
\text { appropriate within some socially constructed } \\
\text { system of norms, values, beliefs and definitions }\end{array}$ \\
\hline Urgency & $\begin{array}{l}\text { The urgency of the stakeholder's } \\
\text { claim on the firm }\end{array}$ & $\begin{array}{l}\text { The degree to which stakeholder claims call for } \\
\text { immediate attention }\end{array}$ \\
\hline
\end{tabular}

profile, sustainability reporting, local context and interesting field competencies like metals recycling. The nature of Boliden AB's operations is described in "The case study context" section. The company is organized into four business units: Mines, Smelters, Treasury and Finance, and Corporate Responsibility.

In order to strengthen the internal validity, the study is performed within the Corporate Responsibility business unit, which is led by the Senior Vice President, Corporate Responsibility (SVPCR). His group consists of the Director of Group Communication (DGC) responsible for the strategic, internal and external communication, the Director of Group Human Resources (DGHR) handling strategic labour practises, and the Director of Group Sustainability (DGS) responsible for the environment, quality and occupational health and safety. This unit is highly relevant for the purpose of this study

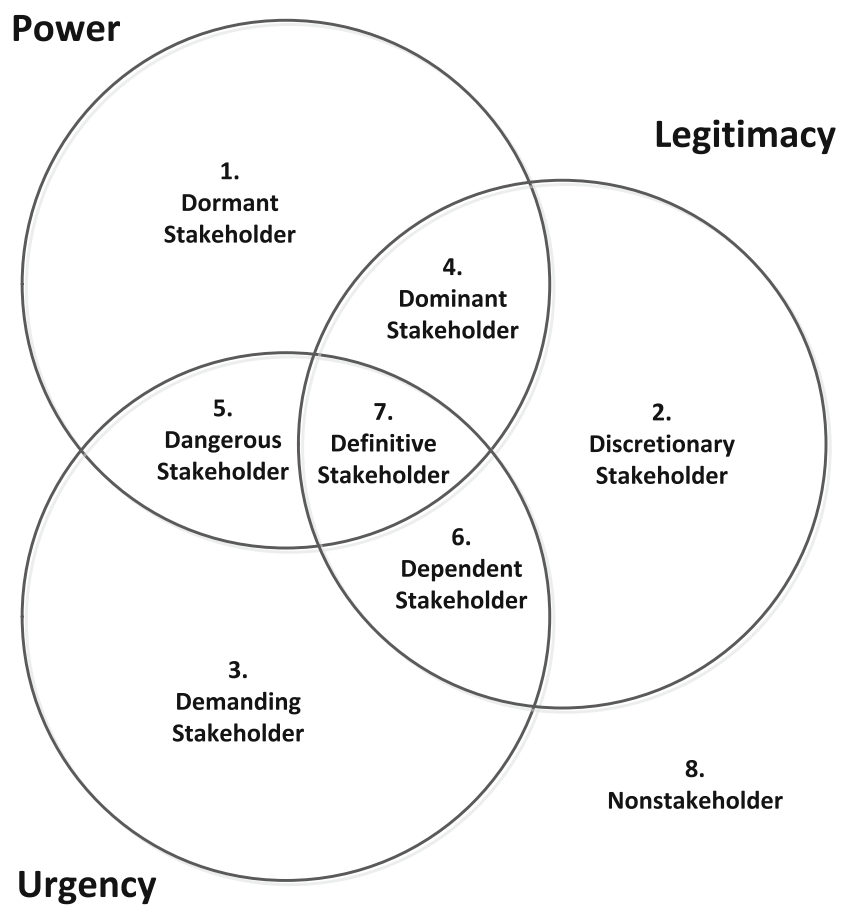

Fig. 3 Mitchell et al.'s (1997) model for stakeholder management and consists of managers with the ultimate responsibility and authority for CSR issues. These four managers are the main respondents in this study and are later in this paper referred to as "the managers". Case study data has been collected via open, face-to-face interviews and interactive workshops. General information about the interviews and the workshops are presented in Table 3.

Interviews were carried out with the SVPCR, the DGS, the Energy Efficiency Manager (EEM), the DGC, the DGHR and the company expert on biodiversity and restoration (CEBR). The open interviews were focusing on the business unit's view on their stakeholder management practice before the theoretical framework was introduced. The main theme was who are the most important stakeholders and how are you interacting with these stakeholders? The interviews were transcribed and data were coded by the coding criteria shown in Table 4.

Interactive research is used to bring theory to practice and can be advantageously used for joint learning between practitioners and researchers (Svensson and Aagaard Nielsen 2006) with the goal to improve practice, develop individuals or transform the practice, practitioners or even organizations (Herr and Anderson 2015). It provides a richness of insight which could not be gained in other ways (Whyte 1991). Researchers can contribute in multiple ways for example with complementary knowledge and by creating opportunities for reflection in order to develop knowledge and gain experience (Johannisson et al. 2008). During the first workshop, the focus was on the theoretical framework and how the company reacted to and appropriated it. In the second workshop, we evaluated the results and discussed if the theoretical framework can be useful to develop the practice of stakeholder management further. The study consists of four steps further described in Table 5.

During the workshops, I have contributed with my knowledge of stakeholder theory as a complement to the knowledge that the managers already possessed. In the process of mediating, I have picked out central parts of the stakeholder theory and tried to simplify and translate them so that practitioners can quickly assimilate the theory. I have also created 
Table 2 The stakeholder classes in Mitchell et al.'s (1997) model are described

\begin{tabular}{|c|c|c|}
\hline \multirow[t]{3}{*}{ Latent stakeholders } & Dormant stakeholder & $\begin{array}{l}\text { Possesses the attribute power. Examples are those who have a loaded gun, } \\
\text { who can spend a lot of money or who can command the attention of the media. }\end{array}$ \\
\hline & Discretionary stakeholder & $\begin{array}{l}\text { Possesses the attribute legitimacy. Examples are non-profit organizations } \\
\text { who receive donations and volunteer labour. }\end{array}$ \\
\hline & Demanding stakeholder & Possesses the attribute urgency. They are the "mosquitoes buzzing in the ears". \\
\hline \multirow[t]{3}{*}{ Expectant stakeholders } & Dominant stakeholder & $\begin{array}{l}\text { Possesses the attributes power and legitimacy. For example owners, significant } \\
\text { creditors, community leaders, employees. }\end{array}$ \\
\hline & Dangerous stakeholder & $\begin{array}{l}\text { Possesses the attributes power and urgency. That stakeholder will be coercive } \\
\text { and possibly violent, making the stakeholder "dangerous" to the firm. }\end{array}$ \\
\hline & Dependent stakeholder & $\begin{array}{l}\text { Possesses the attributes legitimacy and urgency but lack power to act. These } \\
\text { stakeholders have to rely on the advocacy of other, powerful stakeholders } \\
\text { or on benevolence and voluntarism. }\end{array}$ \\
\hline Definitive stakeholders & Definitive stakeholder & $\begin{array}{l}\text { The combination of all three attributes is the "definitive stakeholders" to } \\
\text { which managers give priority. }\end{array}$ \\
\hline
\end{tabular}

opportunities for reflection for example through questions or challenges in order to support the development.

\section{The case study context}

Sweden is a parliamentary democracy where all public power proceeds from the people. All Swedish citizens have the same fundamental freedoms and rights and are entitled to health and medical care, and compulsory schooling that lasts for 9 years. Human rights are safeguarded through the Constitution and other laws and ordinances. In addition, the European Convention for the Protection of Human Rights and Fundamental Freedoms has applied as law in Sweden since 1995. Sweden has a long tradition of promoting gender equality which means that women and men enjoy the same rights and opportunities in all areas of life (Government Offices of Sweden 2014). Regulations governing labour are enshrined in laws, collective agreements and private employment agreements (Swedish Work Environment Authority 2012). Obligations placed on employers and others responsible for safety to prevent ill health and accidents at work and in general contribute to a good work environment, as regulated in the Work Environment Act (1977:1160). This act also contains provisions on cooperation between employers and employees, such as regulations on the activities of safety officers (Sveriges Riksdag 2012). A collective agreement is a written contract which can contain terms of employment and such matters as have been agreed upon between the employer and the employee (Swedish Work Environment Authority 2012). The environmental legislation is regulated by the Swedish Environmental Code aimed at promoting sustainable development and a healthy and good environment. Swedish industry, including the mining sector, is often considered to be rather proactive when it comes to adopting CSR-related initiatives, especially within the areas of environmental and occupational health and safety (OECD 2014; Ammenberg 2012). It is within this cultural context that the case company Boliden $\mathrm{AB}$ is set.

Boliden $\mathrm{AB}$ is a mining and metals company with core competencies in the fields of exploration, mining, smelting and metals recycling. Boliden's main metals are zinc and

Table 3 General information about interviews and workshops

\begin{tabular}{|c|c|c|c|}
\hline Action & Post & Time $(h)$ & Date \\
\hline Interview 1 & Director of Group Sustainability & 2 & 22 August 2012 \\
\hline Interview 2 & Energy Efficiency Manager & 2 & 7 September 2012 \\
\hline Interview 3 & Director of Group Communication & 2 & 11 September 2012 \\
\hline Interview 4 & Director of Group HR & 2 & 11 September 2012 \\
\hline Interview 5 & Senior Vice President, Corporate Responsibility & 2 & 11 October 2012 \\
\hline Interview 6 & The company expert on biodiversity and restoration & 2 & 25 September 2012 \\
\hline Workshop 1 & $\begin{array}{l}\text { Senior Vice President, Corporate Responsibility, Director of Group } \\
\text { Sustainability, Information Manager, Director of Group HR }\end{array}$ & 4 & 26 September 2013 \\
\hline Workshop 2 & $\begin{array}{l}\text { Senior Vice President, Corporate Responsibility, Director of Group } \\
\text { Communication, Director of Group HR, Energy Efficiency } \\
\text { Manager, Health and Safety Manager }\end{array}$ & 1 & 26 May 2014 \\
\hline
\end{tabular}


Table 4 The table presents coding criteria

\begin{tabular}{ll}
\hline Coding criteria & Description of criteria \\
\hline Financiers & $\begin{array}{c}\text { The capital market, shareholders, analysts, } \\
\text { banks, investors } \\
\text { Employees, future employees, trade union } \\
\text { representatives } \\
\text { Employees }\end{array}$ \\
Government & $\begin{array}{c}\text { Authorities, politicians } \\
\text { The local community } \\
\text { Suppliers }\end{array}$ \\
\hline
\end{tabular}

copper, but lead, gold, silver and other products are also important. The group has approximately 4400 employees distributed over four mining areas, six smelters, three marketing offices and one head office. The four mining areas are Aitik, Tara, Garpenberg and the Boliden Area. All mines produce complex ore that contains zinc, copper, lead, gold and silver. Boliden's five smelters refine metal concentrates and other raw materials, such as electronic scrap, metal scrap, metal ashes and end-of-life car batteries, in order to produce both pure metals and customized alloys. Boliden's marketing offices in Sweden, Denmark, the UK and Germany manage sales and the purchasing of raw materials, metals and by-products. The metals and by-products are sold and transported to customers such as steel companies and other manufacturers of semi-finished products.

Boliden's group management has the ultimate responsibility for Boliden's sustainability work, which is conducted through the Corporate Responsibility business unit and group-wide networks. The sustainability work has focussed on employees and environmental responsibility. For the employees, this meant a safe work environment, health and lifestyle programs, and equal opportunities and diversity. The environmental responsibility included environmental management systems, energy consumption, and carbon dioxide emission rights (Boliden 2010). In 2012, sustainable development was given a much more important role and the SVPCR states that "Sustainability has probably never been as important for Boliden as it is right now". The text covering sustainable development went from two to ten pages in their annual reporting, and the focus areas were enlarged with issues like the securement of tomorrow's talent pool, a strategic approach to energy issues, limitation of the impact on the physical environment, sustainable land and forestry management, and the evaluation of business partners (Boliden 2012). This trend for sustainability management issues within the company has continued (Boliden 2013).

\section{The case}

This section presents the results from the four case study steps called managing for stakeholders, the stakeholder view of the firm, the two-tier stakeholder map and evaluating stakeholdermanager relationships with descriptions of how theory was applied and how the managers reacted.

\section{Managing stakeholders}

The purpose of this step was to describe the company's existing stakeholder management practice, before the theory was introduced. The communication with the stakeholders is controlled by a number of documents both on group and local level: Communication policy, Investors Relations policy and instructions for communication. However, these documents do not include any information on how to identify and engage stakeholders. Nevertheless, the company has many stakeholders and extensive work is put into the interaction. The findings are divided into a number of subsections corresponding with the coding criteria presented in Table 4.

\section{Financiers}

The SVPCR stated that Boliden has a lot of extremely critical stakeholders. He considered the capital market and ultimately the shareholders to be the biggest and most important stakeholders. The DGC was more specific and enumerated the

Table 5 The table presents overall information about the four steps of the study

\begin{tabular}{|c|c|c|c|}
\hline Case study steps & Data source & Purpose with data collection & Theory \\
\hline 1. Managing stakeholders & Interviews $1-6$ & To describe the company's existing stakeholder management & \\
\hline 2. The stakeholder view & Workshop 1-2 & To define and identify the company's stakeholders. & (Freeman 1984) \\
\hline 3. The two-tier stakeholder map & Workshop 1-2 & $\begin{array}{l}\text { To divide the stakeholder groups into primary and } \\
\text { secondary stakeholders } \\
\text { To study the level of interaction and the correlation between } \\
\text { the Boliden two-tier map and the actual interaction }\end{array}$ & (Freeman et al. 2007) \\
\hline $\begin{array}{l}\text { 4. Evaluating stakeholder } \\
\text {-manager relationships }\end{array}$ & Workshop 1-2 & $\begin{array}{l}\text { To divide the stakeholders into latent, expecting and } \\
\text { definitive stakeholders }\end{array}$ & (Mitchell et al. 1997) \\
\hline
\end{tabular}


financiers as the shareholders, the ethical analysts, the financial industry, the company's lending banks, Swedbank Robur which is a major shareholder in Boliden, the AP funds, and AMF, which is the pension company focusing on occupational pensions, and international fund managers. They both argued that the financiers have quite stringent requirements for everything to be properly managed.

The DGS also stated that the investors are important stakeholders. She argued that if the company got a bad reputation and neglected its environmental responsibility, nobody would invest in the company and that fact would affect its whole image. She explained how the analysts have ethical funds, and if they believe that the company is behaving unethically, they will expel it from the ethical funds. "Then of course their colleagues next door will buy us up again in another fund that is not called ethical, but that is a different issue", she concluded with a laugh. The DGC gave an example based on experience: "Robur's ethical funds decided some years ago to sell off Boliden since they believed that we did not manage ethically".

They all agreed that Boliden has a well-developed communication with financiers with an effective system and a good dialogue. It has annual capital market days where Boliden representatives meet the analysts, but it is the quarterly reports that get the most attention. The DGC said: "These stakeholders really get the most attention". Other channels for interaction are shareholder meetings, annual meetings and the Internet.

\section{Employees}

The DGS highlighted the employees and their families as very important stakeholders due to the fact that nobody wants his/ her father, mother or children to be injured at work. The DGC also considered the employees as important stakeholders and the interaction is described as a process to raise the level of consciousness. She gave an example:

"Our operations are in Sweden, Finland and Norway. Why should we care about human rights? Well, because we may buy concentrate from other countries far away or maybe we sell metals to companies that in a worst-case scenario do not know how to handle it. That is why".

The communication department uses "storytelling" to spread good practice within the company. For example, an activity that has worked well for one unit can be of help to another unit. If an accident happens somewhere in the organization, it is put on the intranet so that everyone can keep up to date or take preventive actions. This process to raise the level of consciousness and the storytelling is handled through house magazines and the intranet. She concludes by saying: "We are helping to build a culture".

Instead, the DGHR pointed out the potential labour force as the most important stakeholders and explained that this involves a variety of issues from how to get the kids from compulsory school to choose technical or natural science educations to those people who might want to work after retirement. In order to increase the interest in science and to secure tomorrow's skill pool, Boliden promotes and supports education at all levels from the 9-year compulsory school to upper secondary schools and universities in the local community. One example is schooldays devoted to mining, school forests and educational visits to the sites. The DGHR said: "There is not a single kid in the district who has not visited the smelter at Rönnskär". The company also sponsors a resource centre for science and technology. Other channels for interaction are group-wide networks, union meeting forums, general manager meetings, personal development discussions and safety committees.

\section{Government}

The government consists of both the authorities and politicians and the DGC said: "The authorities and local politicians are often very positive to Boliden's operations since they bring employment and people to the community". The DGS described the authorities as a very important stakeholder. She said: "they make requirements on the company and we are dependent on them having confidence in us since it enable us to conduct our business". The DGHR was more specific and named the relevant authorities as the Tax Agency, the Swedish Work Environment Authority and Statistics Sweden, to which Boliden reports data about certain issues as required by law in Sweden. The EEM added the Swedish Energy Agency and the Environmental Protection Agency. He said: "Most of the authorities have committees so it is through these we have to work". Other means for interaction are meetings, studies and projects.

The SVPCR described the political involvement: "We do not engage in the political debate and we do not take a stand on political issues. We comment on certain issues in our area of interest so that policy decisions will be objectively justified". The engagement occurs at various levels. The Group Executive Board has regular contact with the Ministry of the Environment and the Ministry of Enterprise, Energy and Communications and the mines and smelters have regular contacts with local politicians. The DGC concluded: "We are often the largest employer in the local communities and therefore also a major player for the local politicians".

The interaction with the authorities is largely governed by legislation. Some are required by law such as communication in the process for attaining environmental permits, and other contacts concern more voluntary community development initiatives. It is also clear that the company has contact with politicians, but they all believe that these interactions can be improved. The DGC summed it up: “A good structure for how 
we talk to politicians, a continuous dialogue, would be desirable".

\section{The local community}

The stakeholders in the local community are local residents, Sami communities, local media and NGOs. The DGS sees the residents near the facilities as very important stakeholders since it is important that they are able to live their lives in a clean environment. "They should not have to worry that their children are poisoned at their playgrounds or breathing in bad air, or whatever it may be". The local residents keep themselves informed via the Internet. The environmental issues are governed by the authorities, for example through permits. The community involvement is often conducted through sponsorship. Company policy is that sponsoring should be local and that the management of the mines and smelters should decide for themselves which activities to support. The mines and smelters arrange activities in the local community. The DGC gave an example:

"They have regular open house events and these are very popular in Finland by the way. Another example directed at children is the Geology Day where children may pan for gold. Sometimes we invite the local community to briefings, but the interest is low. If there's a free bun, someone might come.... (laughter)".

The CEBR regarded the local residents and the Sami people (indigenous people involved in reindeer herding) as important stakeholders in northern Sweden. "I put a lot of time and effort into maintaining good relations with these stakeholders". The company has established good cooperation with the Sami, and at certain times of the year, when the reindeer herding takes less time, the Sami are employed by Boliden to manage the forest and repair fencing around the sites. Boliden has, to a large extent, adapted its operations to reduce damage to reindeer herding, for example by building reindeer passages and fences. He summarized this by saying: "We have an interest in showing that we can interact and conduct our businesses together with the Sami and if you make an effort to get to know these people, it works really well".

Both the media and NGOs were mentioned quite briefly and not as "important stakeholders", during the interviews. The DGC said that she often sees media as just a channel for communication, but she is aware of their interest in the company and said: "The local media monitor us carefully". Nevertheless, the means of interaction are information, reports, the Internet, meetings, press releases, interviews, etc. Regarding the NGOs, the SVPCR said that they have received comments from Greenpeace, the Swedish Society for Nature Conservation and other local environmental movements, but there has not been any major conflict.
Suppliers

The DGHR said that the suppliers are important stakeholders and gave examples of stakeholders based on her own responsibilities: "The suppliers are, for example, education consultants or those who deliver IT-systems, etc. The suppliers from a HR perspective are quite small if we compare them with Boliden as a whole". The EEM particularly highlighted the energy and equipment suppliers.

\section{The collected view}

The respondents believe that Boliden's stakeholder management practises are extensive but not performed in a systematic manner and the company does not consult the stakeholder groups about what they believe it should focus CSR initiatives on. Boliden's stakeholder management is summarized by the DGC: "If we are up to something, all stakeholders will be interested. But we do not have a collected stakeholder dialogue or a collected structure for how we should meet our stakeholder groups. We have bits and pieces". Boliden's own stakeholder view (version 1) is presented in Fig. 4.

\section{The stakeholder view}

The purpose with the second step was to define and identify the company's stakeholders and to explore how the managers received the stakeholder view of the firm (Freeman 1984). The first task was to define the company stakeholders. Some thoughts and ideas regarding definitions were shared among the group, but nothing concrete was generated. In order to help the discussions, numerous definitions of a stakeholder were presented, via the chronology presented by Mitchell et al. (1997). The reaction from the managers and especially from the SVPCR was that these definitions were "too academic". After further thoughts, reflections and discussions, the

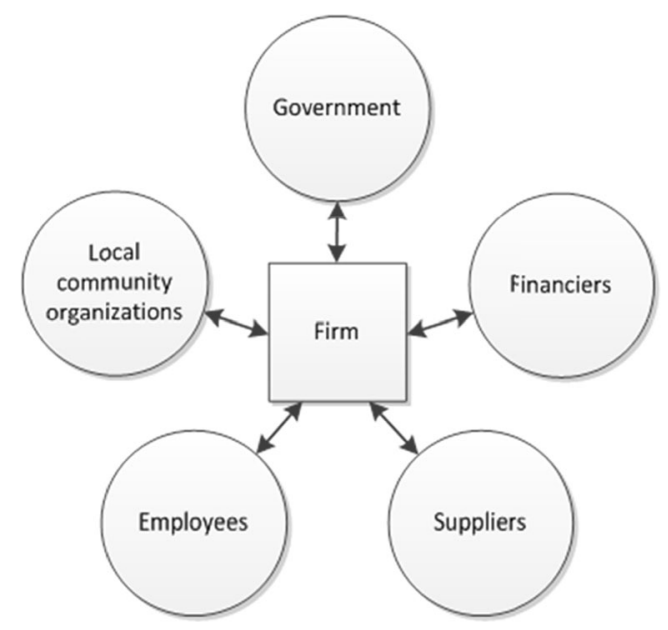

Fig. 4 The Boliden stakeholder view 1.0 
managers agreed to the definition "can affect or can be affected by business" influenced by Freeman and Gilbert (1987). The managers believed the chosen definition to be plain and easy to comprehend.

The next task was to identify the company stakeholders, so the stakeholder view of the firm (Freeman 1984) was presented. The managers' suggestions for stakeholder groups were written down on post-it notes and placed on a whiteboard with the company in the middle. The suggestions were rapidly delivered and often connected to the managers' own responsibilities. This resulted in employees, trade-union representatives, future employees, the capital market, lenders, stock exchange analysts, neighbours, owners, business partners, customers, suppliers, contractors, consumers, university/research, competitors, Sami communities, politicians, the media, public opinion formers, NGOs, trade-unions, business associations, authority and landowners. They recognized that theory had less stakeholder groups and discussed if they should modify the result. They realized that some of the suggested stakeholder groups actually were sub-groups to other stakeholder groups. So, the public opinion formers include NGOs, business associations, and trade unions. The capital market includes lenders and stock exchange analysts. The employees include trade-union representatives. Finally, the business partners include customers, suppliers and contractors. The "Boliden stakeholder view (version 2)" is presented in Fig. 5.
Compared to theory, the company has more stakeholder groups. Instead of government and financiers, it has authorities, politicians, capital market and owners. Boliden also has future employees as a primary stakeholder due to the current problem of finding qualified labour. The DGS described: "We need qualified employees in order to operate our business in a good way. To attract the qualified employees, we must have a constant dialogue and market ourselves towards them". The SVPCR continued: "An on-going dialogue with future employees is most important. That is not so important with the Sami communities or the landowners". Instead of communities, the managers chose to fine-tune it into neighbours, Sami communities, landowners and university/research.

\section{The two-tier stakeholder map}

During the third step, the managers divided the stakeholder groups into primary and the secondary stakeholders (Freeman et al. 2007). When the managers were asked to fine-tune the Boliden stakeholder view, they moved the post-it notes on the whiteboard with the "primary stakeholders" closer to the middle (the firm) and the "secondary stakeholders" further out. The work was performed quite quickly in an efficient, cooperative and enthusiastic manner without any divergent opinions. The result, the "Boliden two-tier stakeholder map", is presented in Fig. 6.

Fig. 5 The Boliden stakeholder view 2.0

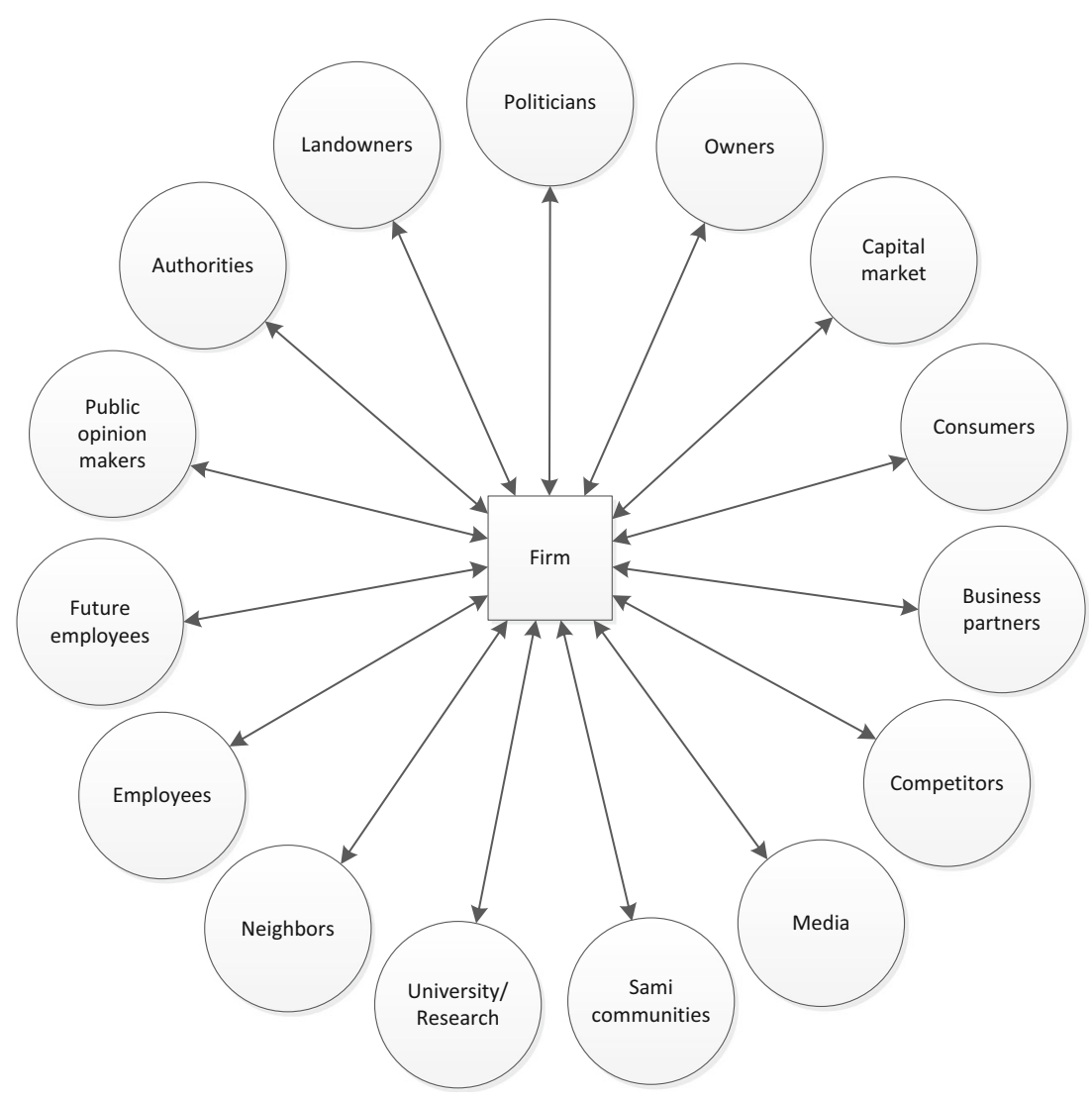




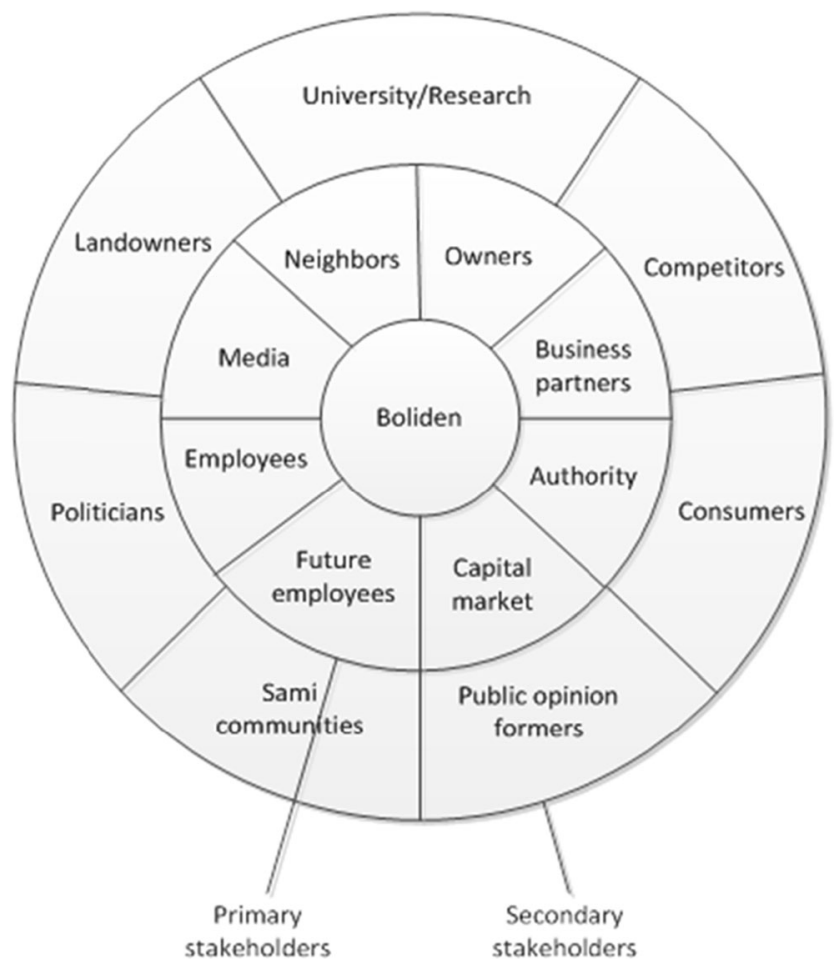

Fig. 6 The Boliden two-tier stakeholder map inspired by Freeman et al. (2007)

The original "stakeholder two-tier map" (Freeman et al. 2007) was presented retroactively and comparisons were made between the two. One difference was that Boliden had put the authorities in the inner circle. This can be explained by the Swedish context where the legislation and the labour movement are important drivers. Boliden had also put the media as a primary stakeholder, while Freeman et al. (2007) consider the media as a secondary stakeholder. The DGC said that the media is tricky and that she always has seen the media as just a channel for reaching the other stakeholders, but in reality, they are public opinion makers and communicators. The SVPCR continued: "The media is more than just that, they are the fourth estate". The DGHR also justified the media as a "primary stakeholder": "We do not have customers like Volvo (provides transportation related products) or Atlas Copco (provides equipment and service for industry), our customer segment is much narrower. We need to be seen and that is why the media is so important". The final conclusion was that mass communication technology has changed the role of the media with regard to business.

The similarities between Freeman et al.'s (2007) and Boliden's "two-tier stakeholder map" is that both placed financiers (capital market and owners), employees and business partners as primary stakeholders and competitors, consumers and public opinion makers as secondary. They all believed that this model could be used as a model for the company to assess its stakeholders.
Then, the level of interaction between the company and the identified stakeholder groups was discussed in order to study how well the Boliden two-tier stakeholder map correlated with the actual interaction. The managers were asked to draw arrows on the whiteboard from the firm to the stakeholder groups. Thick arrows were used to represent the fact that a lot of time and effort was put into interaction, the thin arrows to represent little time and effort, and the medium-thick arrows something in between. This was also performed rather quickly without any divergent opinions and the result is presented in Fig. 7.

In general, the managers have thicker arrows to the stakeholders in the inner circle and thinner in the outer. However, the figure also shows that even if the future employees, neighbours and the media are seen as primary stakeholders, the interaction is perceived as rather poor.

\section{Evaluating stakeholder-manager relationships}

The fourth step was to estimate "who and what really counts" according to the theory by Mitchell et al. (1997) where the stakeholders are evaluated based on three relationship attributes: power, legitimacy and urgency.

Theory was presented to the group including explanations and definitions for the three attributes, which is seen in Table 2. The SVPCR commented on the definition for legitimacy: "That was very theoretical, what does that mean?" In order to clarify the attribute, examples were presented about what legitimacy could mean in their specific context. The group concluded that it is rather hard to work with the model if you do not understand the definitions, so they wanted to create their own definitions of the relationship attributes where needed.

The definition of the attribute "power" generated a lot of discussion among the group. The SVPCR strongly believed that the presented definition of power (Mitchell et al. 1997) was the most accurate one. The DGS and the DGC believed that "the stakeholders" capacity to directly or indirectly affect the company was better. After some thought, the DGHR argued: "Power, I believe it should be the direct capacity to affect the company... those who can affect the company here and now". The DGC answered: "Yes, but if you think like this, the media can affect the company by affecting our future employees, so that they do not want to work at Boliden because we have got a bad image". The DGHR argued: "If our employees in Aitik for some reason decide to stop driving the trucks...then, they affect the company very much and at once". The SVPCR agreed. The DGS suggested: "Cannot it be both?" and continued: "What is power anyway?" The SVPCR concluded: "It's all about just that, to influence someone to do something they would not otherwise have done", and referred back to the original definition. The DGS and the DGC still believed that "the stakeholders" capacity to directly 
Fig. 7 The estimated time and effort put into the interaction with stakeholder groups

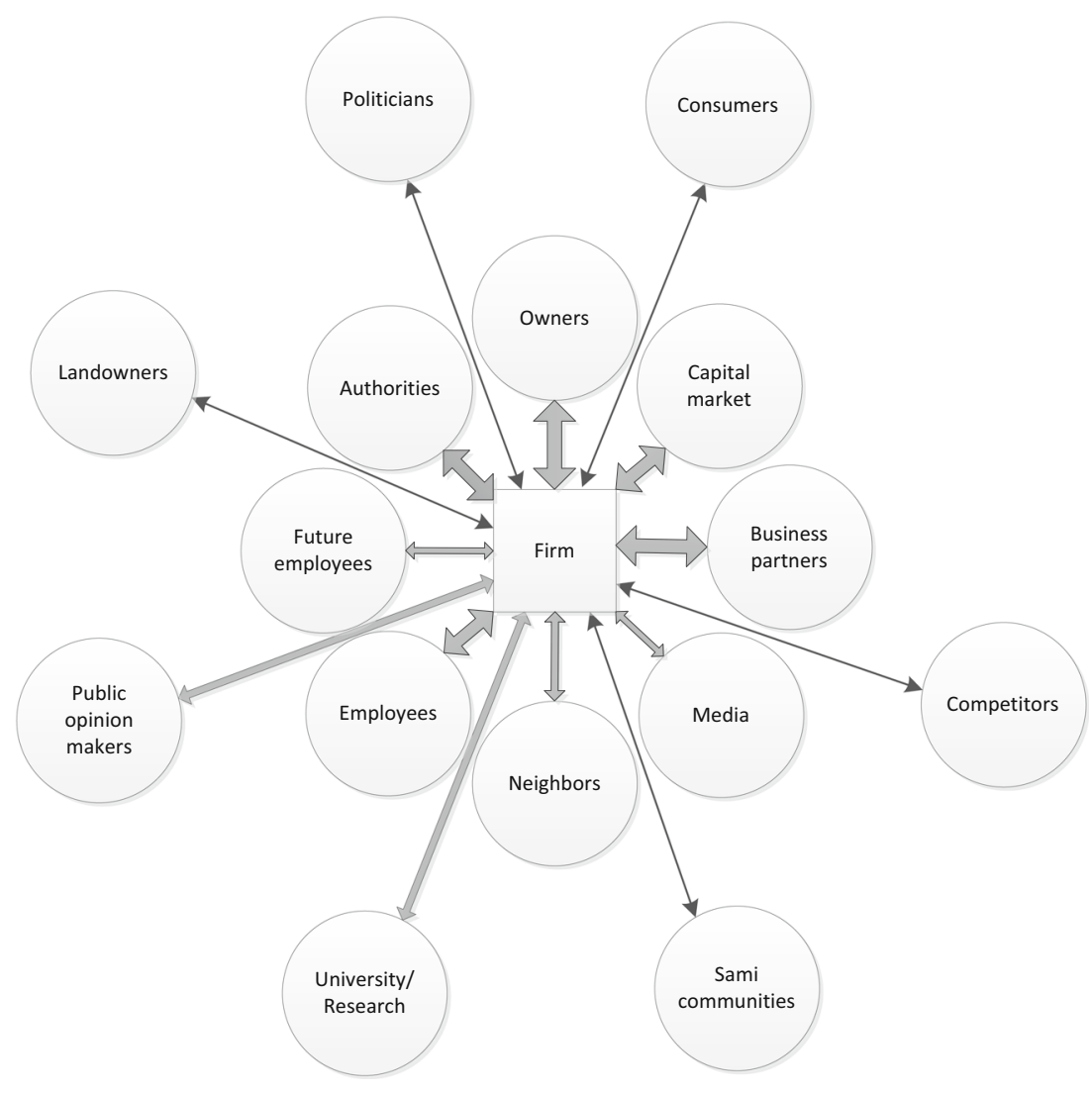

or indirectly affect the company was the correct definition. After further discussions, the SVPCR abstained even if he persisted in his opinion that the new definition was "very nonspecific".

By contrast, the definition for legitimacy was decided very quickly. The DGS tried to describe her thoughts about the attribute by asking whether a stakeholder has the right to exercise influence and the others developed the discussion. The DGC asked: "Who is to define if they have that right or not?" The SVPCR answered: "Well, that will be defined by our norms and values". The definition presented for urgency was finally chosen after some discussions about whether the word "immediate" should be included or not. The DGC was pondering about the time span for "immediate", while the SVPCR argued that the word had to be included in order to define urgency. Boliden's definitions of the attributes are presented in Table 6.

The previously identified stakeholder groups were written down on a whiteboard and evaluated based on the three redefined relationship attributes with a "yes" or a "no". After a while, they realized that all stakeholder groups were being evaluated as having all three attributes: power, legitimacy and urgency. They found it hard to adjust to just two alternatives, yes and no, and called for "some". Since that was not an option, they read the definitions again and restarted with the primary stakeholders and the task got easier. The final evaluation is presented in Table 7 .

The stakeholder group that required most discussion was the competitors. In the discussion about competitors and power, the opinions differed. The DGS said: "Yes, they have some

Table 6 The relationship attributes with the original and the company's own definitions

\begin{tabular}{|c|c|c|}
\hline Relationship attribute & Definition & Boliden's definition \\
\hline Power & $\begin{array}{l}\text { A relationship among social actors in which one social actor, A, } \\
\text { can get another social actor, B, to do something that B would } \\
\text { not have otherwise done }\end{array}$ & $\begin{array}{l}\text { The stakeholders' capacity to directly or indirectly } \\
\text { affect the company }\end{array}$ \\
\hline Legitimacy & $\begin{array}{l}\text { A generalized perception or assumption that the actions of an } \\
\text { entity are desirable, proper, or appropriate within some socially } \\
\text { constructed system of norms, values, beliefs, definitions }\end{array}$ & $\begin{array}{l}\text { The stakeholders' right to exercise influence on } \\
\text { the company within its system of fundamental values }\end{array}$ \\
\hline Urgency & The degree to which stakeholder claims call for immediate attention & $\begin{array}{l}\text { The degree to which stakeholder claims call for } \\
\text { immediate attention }\end{array}$ \\
\hline
\end{tabular}


Table 7 The evaluation of stakeholder groups based on the relationship attributes with the company's own definitions

\begin{tabular}{llll}
\hline Stakeholder & Power & Legitimacy & Urgency \\
\hline Employees & Yes & Yes & Yes \\
Future employees & No & Yes & Yes \\
Capital market & Yes & Yes & Yes \\
Neighbours & Yes & Yes & Yes \\
Owners & Yes & Yes & Yes \\
Business partners & Yes & Yes & Yes \\
Consumers & No & Yes & No \\
University/Research & No & Yes & No \\
Competitors & No & Yes & No \\
Sami communities & Yes & Yes & No \\
Politicians & Yes & Yes & No \\
Media & Yes & Yes & Yes \\
Public opinion makers & Yes & Yes & Yes \\
Authority & Yes & Yes & Yes \\
Land owners & No & Yes & No \\
\hline
\end{tabular}

power, because they can drive us out of the market". The DGC responded: "Well, I believe that they have no power, actually...." The DGHR argued: "But, they drive us out of market.....in some situations". The DGC continued: "Yes, but in our stakeholder dialogues with our competitors, can we affect them so that they don't drive us out of market?" The SVPCR continued: "Can they make us do something that we otherwise should not have done?... the answer is yes. They can take our customers and our future employees...." The DGS responded: "Yes, I actually believe that they have power". The discussion about competitors and legitimacy was shorter. The DGS said: "The competitors are in the same business, so they have legitimacy". The others agreed. Grading the competitors as regards the attribute "urgency" was harder. The DGHR said: "They will have to wait!" The SVPCR replied: "If we were to ask the sales manager, I'm pretty sure he would strongly argue for urgency regarding the competitors". The DGC was doubtful and said: "I am curious, if we define our competitors as primary stakeholders, what would this shift in stakeholder management look like? The fact that we suddenly should focus our stakeholder dialogues on the competitors". After some consideration, the DGS said: "I do not think that the competitors have power... after all..." The SVPCR replied: "But surely they have power?" The DGC continued: "But not the same immediate power as owners, authority or employees". The SVPCR said: "I believe that we are influenced by our responsibilities within the company and that others, for example, based on commercials would rate them differently". He continued:

"LKAB is not a competitor businesswise or on the capital market and we sell everything we produce so that competition is put out of action, while on the other hand, we compete about future employees, technical development, and environmental performance. That's where the competition is".

The DGC continued: "But this is about a stakeholder dialogue, and from that perspective, are competitors a stakeholder group that we should have a dialogue with?" The SVPCR replied: "No, they are not". The DGC said: "No, we cannot say that". The SVPCR finished the discussion: "No, we leave them..." The final grading is presented in Table 6.

Another stakeholder group that generated discussions was, once again, the media. The managers all agreed that the media have power, but then it got harder. The DGC argued: "Then they take legitimacy", and she continued: "I don't think the model is applicable for the media". The others agreed. She continued further: "Nevertheless, it has to be 'yes' there; we can never say that media do not have 'legitimacy' to write about whatever they want. It falls under the freedom of the press. It has to be a 'yes' there". The SVPCR proceeded with "urgency" and said: "It can also be very urgent". The DGS summarized the evaluation for the media by saying: "If we generalize about the media it has to be 'yes' on all three attributes". The evaluation for the other stakeholder groups was performed rather quickly. The final result is presented in Table 8 . The managers summarized the work with this model as not only difficult but also very useful since they had to look at the stakeholders from different perspectives.

The differences in the result from the earlier assessment into primary and secondary stakeholders are that the future employees, considered as primary stakeholders in the earlier model, now are dependent stakeholders, i.e. less important and that the public opinion makers go from being secondary stakeholders to definitive, primary stakeholders.

Table 8 The evaluation of stakeholder groups based on Boliden's definitions

\begin{tabular}{|c|c|c|}
\hline $\begin{array}{l}\text { Latent } \\
\text { stakeholders }\end{array}$ & $\begin{array}{l}\text { Discretionary } \\
\text { stakeholder }\end{array}$ & Consumers \\
\hline & & University/Research \\
\hline & & Competitors \\
\hline & & Landowners \\
\hline \multirow[t]{3}{*}{ Expectant stakeholders } & Dominant stakeholder & Sami communities \\
\hline & & Politicians \\
\hline & Dependent stakeholder & Future employees \\
\hline \multirow[t]{8}{*}{ Definitive stakeholders } & Definitive stakeholder & Employees \\
\hline & & Capital market \\
\hline & & Neighbours \\
\hline & & Owners \\
\hline & & Business partners \\
\hline & & Media \\
\hline & & Public opinion makers \\
\hline & & Authority \\
\hline
\end{tabular}


A comparison was made between the two models and the level of interaction was estimated in Figs. 6 and 7 and Table 8. The future employees have a medium-sized arrow which supports Mitchell et al.'s (1997) model. The public opinion makers have also a medium-sized arrow which supports Freeman et al.'s (2007) model. To sum up, the result from the two models is almost the same.

\section{Discussion and conclusions}

It is an obvious fact that the managers, dependent on who they are and their role in the company, are putting the emphasis on different stakeholders. The financiers, defined as the capital market and the shareholders, were seen as the biggest and most important stakeholders. The company has a welldeveloped communication with the financiers with a system for this and a good dialogue, and it is obvious that these stakeholders get the most attention from their point of view. The employees are also seen as very important stakeholders as well as the authorities with an explicit management in place to deal with them. With the politicians and the local community, the interaction was not performed in a systematic manner and was more of a "bits and pieces" approach. This indicates that Boliden has a more traditional, managerial view (Freeman 1984) of a company, where the needs of owners and employees are put first. This bits and pieces approach also proves that Boliden is powerful; otherwise, they would not be able to have this approach.

The SMS planning phase starts with the identification of stakeholders (Singh et al. 2007; Azapagic 2003). The "stakeholder view of the firm" was efficient for use as a roadmap and facilitated the work of identifying stakeholders. It also helped the company to emphasize stakeholder groups that it had not highlighted before in their existing stakeholder management practice. The result was an expanded number of stakeholder groups as a consequence when the company adapted the original stakeholder view to its own context. Important to remember is that the stakeholder groups are not static actors and can change over time (Grafström et al. 2008); therefore, it is important that SMS guidelines instruct the management to update the "Boliden stakeholder view" regularly.

In traditional management systems, the aspects in focus are evaluated and the significant aspects are identified. These significant aspects are then taken into account in establishing, implementing and maintaining the management system. Similarly, an evaluation for the stakeholders is desirable since it can be difficult to work in a good way with all simultaneously. The stakeholder groups were divided into primary and secondary stakeholders. The managers felt that the two-tier stakeholder map was useful for future stakeholder management practice. Some differences between the original map and "Boliden's two-tier stakeholder map" were identified.
Boliden put authorities in the inner circle as primary stakeholders, and this can be explained by the Swedish context where the legislation and the labour movement are important drivers. This is supported by Matten and Moon (2008) who have compared the USA with Europe and have identified differences like the power of the state, governments' engagement in economic and social activity, financial sources, and education and labour systems. Boliden also classified the media as a primary stakeholder, while Freeman et al. (2007) consider the media as a secondary stakeholder. The managers argued that mass communication technology has changed the role of the media with regard to business. Reputation has become more and more important, and negative publicity in the media can result in significant consequences (Grafström et al. 2008); this view is obviously shared by the managers. Berry (2003) does not find the framework with primary and secondary stakeholders overly useful because various stakeholders claim differing degrees of power at different times, and different stakeholders are more significant than others in different industries. If this model was integrated into a SMS, it would be important to adapt the theory to its specific industry and update the model regularly to be more sensitive to changes over time.

The level of interaction between the company and the identified stakeholder groups was estimated and compared with the Boliden two-tier map. This comparison showed that the company had a rather poor interaction with some of the primary stakeholders and this finding is of course valuable information for their future CSR practice. This could be a useful exercise when monitoring and evaluating the SMS.

The model for evaluating stakeholder-manager relationships was more of a challenge for the managers. The definitions for the three attributes were perceived as "very theoretical", and they wanted to re-define them in order to make them more comprehensible and therefore more useful. Again, the managers adapted the theory to its own context. This re-defining and the following evaluation took some time to perform and generated quite long but fruitful discussions.

One conclusion is that the company evaluated all stakeholders as legitimate. Mitchell et al. (1997) state that many scholars make an assumption that legitimate stakeholders are necessarily powerful, when this is not always the fact. This study proves their case since the company evaluated future employees, consumers, university/research, competitors and landowners as legitimate even though they do not possess power. Berry (2003) raises the fact that a shift in relative power may occur because of the importance of the demands on the company or the attention of media. Any single stakeholder can also form coalitions with other stakeholders, thus increasing their power quickly. This suggests that a SMS has to guide management into re-evaluate the stakeholder-manager relationships on a regular basis for the model to be useful. 
The Boliden two-tier stakeholder map and the model for evaluating stakeholder-manager relationships generated almost the same result. Nevertheless, Mitchell et al.'s (1997) model has some advantages. It has a more objective evaluation based on three attributes. It also has three levels, latent, expectant and definitive stakeholders that give a more nuanced evaluation, and finally, the different stakeholder classes can be used to have properly designed dialogues with the stakeholders. Hence, this empirical case study supports the earlier conceptual papers (Asif et al. 2011a, ) and suggest Mitchell et al.'s (1997) model for the initial step of SMS i.e. the identification of stakeholders and the estimation of "who and what really counts".

The conceptual frameworks for SMS suggested by Singh et al. (2007), Azapagic (2003), (Castka et al. 2004) and Rocha et al. (2007) would also benefit from this model. Singh et al. (2007) suggest stakeholder mapping and have on forehand decided who the "relevant" stakeholders are. But, important to remember is that the stakeholder groups are not static actors and can change over time (Grafström et al. 2008) and the suggested model can overcome this issue. Both Azapagic (2003) and Castka et al. (2004) talk about "identification of stakeholders" and a dialogue in order to identify needs and expectations. If we take Boliden as the example, this would mean dialogues with 15 stakeholder groups instead of seven "definitive". Rocha et al. (2007) see the stakeholders as the battery that powers the rest of the SMS. Later on, they talk about building partnership with key stakeholders but nothing about how these key stakeholders are identified. Mitchell et al.'s model could improve these frameworks by identifying "who and what really counts".

Boliden is a heterogeneous company and the SVPCR commented that the result from the workshops might look very different if performed at another business unit. This is supported by Wheeler et al. (2002) who state that even though a company can have stakeholder-responsive behaviour at the corporate, strategic level, this does not mean that the same goes for the subsidiary business units. Perhaps, the main challenge for SMS will be to incorporate all business units in the stakeholder management and then to implement this into the whole company. In conclusion, this paper describes how stakeholder management theory can develop corporate sustainability management, but it does not increase a deeper understanding about mechanisms why who and what really counts in corporate decision making. This would be an interesting subject for future research.

Open Access This article is distributed under the terms of the Creative Commons Attribution 4.0 International License (http:// creativecommons.org/licenses/by/4.0/), which permits unrestricted use, distribution, and reproduction in any medium, provided you give appropriate credit to the original author(s) and the source, provide a link to the Creative Commons license, and indicate if changes were made.

\section{References}

Ammenberg J (2012) Miljömanagment; Miljö- och hållbarhetsarbete i företag och andra organisationer. 2., [rev.] uppl. Lund: Studentlitteratur AB

Asif M, Searcy C, Garvare R, Ahmad N (2011a) Including sustainability in business excellence models. Total Qual Manag Bus Excell 22: 773-786

Asif M, Searcy C, Zutshi A, Fisscher OAM (2011b) An integrated management systems approach to corporate social responsibility. J Clean Prod 56:7-17

Azapagic A (2003) Systems approach to corporate sustainability: a general management framework. Process Safety and Environmental Protection: Transactions of the Institution of Chemical Engineers $81: 303-316$

Berry GR (2003) Organizing against multinational corporate power in cancer alley. Organization and Environment 16:3-33

Boliden (2010) Annual report

Boliden (2012) Annual report

Boliden (2013) Annual report

Castka P, Bamber CJ, Bamber DJ, Sharp JM (2004) Integrating corporate social responsibility (CSR) into ISO management systems - in search of a feasible CSR management system framework. TQM Magazine 16:216-224

Ciliberti F, Pontrandolfo P, Scozzi B (2008) Investigating corporate social responsibility in supply chains: a SME perspective. J Clean Prod 16: $1579-1588$

Deming WE (1986) Out of the crisis: quality, productivity and competitive position. Cambridge Univ. Press, Cambridge

Donaldson T, Preston LE (1995) The stakeholder theory of the corporation: concepts, evidence, and implications. Acad Manag Rev 20:6591

Dunfee TW (2008) Stakeholder theory. Managing corporate social responsibility in a multiple actor contex. In: Crane A, McWilliams A, Matten D, Moon J, Siegel DS (eds) The Oxford handbook of corporate social responsibility. University Press, Oxford

Eisenhardt KM, Graebner ME (2007) Theory building from cases: opportunities and challenges. Acad Manag J 50:25-32

Esquer-Peralta J, Velazquez L, Munguia N (2008) Perceptions of core elements for sustainability management systems (SMS). Manag Decis 46:1027-1038

Freeman RE (1984) Strategic management: a stakeholder approach. Pitman Publishing, Boston

Freeman RE, Gilbert DR (1987) Managing stakeholder relationships. In: Sethi SP, Falbe CM (eds) Business and society: dimensions of conflict and cooperation. Lexington Books, Lexington

Freeman RE, Harrison JS, Wicks AC (2007) Managing for stakeholders: survival, reputation, and success. Yale University Press, New Haven

Frooman J (1999) Stakeholder influence strategies. Acad Manag Rev 24: $191-205$

Government Offices of Sweden (2014) How Sweden is governed [Online]. Stockholm. Available: http://www.government.se. Accessed 5 december 2014

Grafström M, Göthberg P, Windell K (2008) CSR: Företagsansvar i förändring. Liber $\mathrm{AB}$, Malmö

Herr K, Anderson GL (2015) The action research dissertation. SAGE Publications Ltd, Thousand Oaks

Holton I, Glass J, Price ADF (2010) Managing for sustainability: findings from four company case studies in the UK precast concrete industry. J Clean Prod 18:152-160

Hörisch J, Freeman E, Schaltegger S (2014) Applying stakeholder theory in sustainability management: links, similarities, dissimilarities, and a conceptual framework. Organization \& Environment (Article in press)

ISO (2010) Guidance on Social Responsibility (ISO 26000:2010, IDT) 
Jensen T, Sandström J (2011) Stakeholder theory and globalization: the challenges of power and responsibility. Organ Stud 32:473-488

Johannisson B, Gunnarsson E, Stjernberg T (2008) Gemensamt kunskapande: den interaktiva forskningens praktik. Växjö University Press, Göteborg

Kemp D, Boele R, Brereton D (2006) Community relations management systems in the minerals industry: combining conventional and stakeholder-driven approaches. Int J Sustain Dev 9:390-403

Laplume AO, Sonpar K, Litz RA (2008) Stakeholder theory: reviewing a theory that moves us. J Manag 34:1152-1189

Matten D, Moon J (2008) "implicit" and "explicit" CSR: a conceptual framework for a comparative understanding of corporate social responsibility. Acad Manag Rev 33:404-424

Melé D (2008) Corporate social responsibility theories. The Oxford handbook of corporate social responsibility. University Press, Oxford

Miles MB, Huberman AM (1994) Qualitative data analysis: an expanded sourcebook. Sage Publications, Thousand Oaks

Minoja M (2012) Stakeholder management theory, firm strategy, and ambidexterity. J Bus Ethics 109:67-82

Missonier S, Loufrani-Fedida S (2014) Stakeholder analysis and engagement in projects: from stakeholder relational perspective to stakeholder relational ontology. Int J Proj Manag 32:1108-1122

Mitchell RK, Agle BR, Wood DJ (1997) Toward a theory of stakeholder identification and salience: defining the principle of who and what really counts. Acad Manag Rev 22:853-886

OECD (2014) Environmental performance review of Sweden [Online]. Available: http://www.oecd.org/environment/countryreviews/33843590.pdf. Accessed 31 March 2014

Parent MM, Deephouse DL (2007) A case study of stakeholder identification and prioritization by managers. J Bus Ethics 75:1-23

Ranängen H, Zobel T (2014) Revisiting the 'how' of corporate social responsibility in extractive industries and forestry. Journal of Cleaner Production In press

Rocha M, Searcy C, Karapetrovic S (2007) Integrating sustainable development into management systems. Total Qual Manag Bus Excell 18: 83-92

Sebhatu SP, Enquist B (2007) ISO 14001 as a driving force for sustainable development and value creation. TQM Magazine 19:468-482
Shahin A, Zairi M (2007) Corporate governance as a critical element for driving excellence in corporate social responsibility. International Journal of Quality and Reliability Management 24:753-770

Singh RK, Murty HR, Gupta SK (2007) An approach to develop sustainability management systems in the steel industry. World Review of Entrepreneurship, Management and Sustainable Development 3: 90-108

Starik M, Marcus AA, Illitch A (2000) Special research forum: the management of organizations in the natural environment. Acad Manag J 43:539-736

Stieb JA (2009) Assessing Freeman's stakeholder theory. J Bus Ethics 87: 401-414

Sullivan R (2004) Integrating human rights and environmental Mangement. Corp Environ Strateg 11:225-232

Svensson L, Aagaard Nielsen K (2006) Action and interactive research: beyond practice and theory. Shaker Publishing, Maastricht

Sveriges Riksdag (2012) Lag (1982:80) om anställningsskydd [Online]. Available: http://www.riksdagen.se/sv/DokumentLagar/Lagar/Svenskforfattningssamling/ Lag-198280-omanstallningss_sfs-1982-80/. Accessed 28 september 2012

Swedish Work Environment Authority (2012) Swedish labour legistation [Online]. Available: http://www.av.se/inenglish/working/labour_ legislation. Accessed 10 october 2012

Weber J, Wasieleski DM (2003) Managing Corporate Stakeholders. The journal of Corporate Citizenship 9:133-153

Wheeler D, Fabig H, Boele R (2002) Paradoxes and dilemmas for stakeholder responsive firms in the extractive sector: lessons from the case of Shell and the Ogoni. J Bus Ethics 39:297-318

Whyte, W., F. (1991). Social theory for action: how individuals and organizations learn to change. Newbury Park, Calif:: Sage

Yin RK (2009) Case study research: design and methods. SAGE Publications, Inc., Thousand Oaks

Zadek S (2004) The path to corporate responsibility. Harv Bus Rev 82: $125-132$

Zwetsloot GIJM (2003) From management systems to corporate social responsibility. J Bus Ethics 44:201-207 